\title{
Middle Pleistocene human occupation in the interior of the Iberian Peninsula during cold climate conditions: Zooarchaeology and taphonomy of ETB-H02 site in the Manzanares valley (Madrid, Spain)
}

\author{
José Yravedra ${ }^{a,{ }^{*}}$, Joaquín Panera ${ }^{\mathrm{b}}$, Susana Rubio-Jara ${ }^{\mathrm{b}}$, Alfredo Pérez-González ${ }^{\mathrm{b}}$, \\ Nuria Gallego ${ }^{a}$, Iván González ${ }^{a}$ \\ a Departamento de Prehistoria, Universidad Complutense de Madrid, C/ Prof. Aranguren s/n, 28040, Madrid, Spain \\ b CENIEH, Centro Nacional de Investigación sobre la Evolución Humana, Paseo de la Sierra de Atapuerca 3, 09002, Burgos, Spain
}

\section{A R T I C L E I N F O}

\section{Article history:}

Received 28 January 2018

Received in revised form

28 February 2018

Accepted 16 March 2018

Available online $\mathrm{xxx}$

\section{Keywords:}

Middle pleistocene

Ancient palaeolithic

Taphonomy

Manzanares valley

Iberian peninsula

Cold climate

\begin{abstract}
A B S T R A C T
Evidence suggesting human occupation in the interior of the Iberian Peninsula during cold periods of the Middle Pleistocene is scarce. The Estanque de Tormentas (ETB-H02) site (Manzanares Valley, Madrid) matches with a MIS 6 or MIS 7 cold event, which allows us to tackle the study of the human occupation of the highlands of the Spanish Meseta during a cold climate event.

ETB-H02 is one of the few Middle Pleistocene open air sites of the Iberian Peninsula where lithic industry associated with faunal remains has been preserved. The bone remains have been recovered from several different stratigraphic levels excavated in an area $1029 \mathrm{~m}^{2}$. It can be inferred from the taphonomic and zooarcheological analyses of those remains that occasional human occupations occurred at this site, during which lithic tools were used for processing individuals of aurochs, horses, wild donkeys and deer. In addition, carcasses of animals that probably died due to natural causes have been preserved. Some were modified by carnivores although not intensively, judging by the scarce number of tooth marks.

In conclusion, ETB-H02 supports the hypothesis that the continental climate and the height of the highlands of the Iberian Peninsula were not an obstacle to occupation in the Middle Pleistocene cold times. Besides, unlike other sites of the interior of the Iberian Peninsula that show occasional occupations, in ETB-H02 the human occupation happened recurrently, as human-processed faunal remains have been recovered from different levels and sub-levels, implying repeated visits to this environment, which would offer specific advantages regarding the exploitation of animal resources.
\end{abstract}

() 2018 Elsevier Ltd and INQUA. All rights reserved.

\section{Introduction}

The discussion about the human occupation of the interior lands of Iberia -which are dominated by the highlands of the Spanish Meseta-during cold periods has been a controversial one. The impact of the height on the climate, together with the continentality of the area could have prevented the peopling of this area (Straus, 1991; Corchón, 1997; D'Errico and Sánchez-Goñi, 2003; Vaquero, 2006). However in the last decade it has been proposed that, despite the tough climatic conditions, occupation did occur during cold periods of the Late Pleistocene in the inner

\footnotetext{
* Corresponding author.

E-mail address: jyravedr@ghis.ucm.es (J. Yravedra).
}

area of Iberia (Cacho et al., 2012, 2016; Alcaraz et al., 2013, 2017; Yravedra et al., 2016), even in the harshest times of the climatic maximum (Cacho et al., 2016). However, evidence suggests human occupations in cold moments of the Middle Pleistocene in the Iberian Peninsula are highly limited.

The greatest concentration of Middle Pleistocene sites has been found in the middle Tagus basin, in the Southern Meseta (RubioJara et al., 2016 and references quoted there). The sites where suggesting a climatic framework has been feasible, correspond with mild paleoclimatic events (Rubio-Jara et al., 2016; Santonja et al., 2016; López-Recio, 2017; Blain et al. in this volume), which could suggest that this area was not occupied during cold periods. Most of these sites are located in the Manzanares and Jarama valleys (hereafter MJV) (Panera, 2009; Baena and Baquedano, 2010; RubioJara, 2011; Silva et al., 2013; Rubio-Jara et al., 2016), and are the only 
Middle Pleistocene ones with lithic industry associated with faunal remains.

A good deal of the archaeological sites of MJV are known since the early 20th century, some even since the 19th (Panera and Rubio-Jara, 2002). Therefore, they were excavated in an early time of the research on the Pleistocene, with a methodology that does not allow the inference of issues related to climate or functionality of the settlements. However, in the last decades, sites that have provided valuable information for the study of the human behaviour during the ancient Palaeolithic have been excavated.

Remains of E. (Palaeoloxodon) antiquus showing clear evidence of human processing were found in Áridos 1 and Áridos 2 (Santonja et al., 1980). In Áridos 2, cut marks probably caused during evisceration were identified on the ventral side of the ribs, which implies that humans had access to the carcass earlier than the carnivores (Yravedra et al., 2010). Evidence of human processing of Palaeolodoxon antiquus have also been found in Tafesa and Arriaga IIa (Rus and Vega, 1984; Baena and Baquedano, 2010; Panera et al., 2014), together with remains of deer and aurouch, also with traces of human activity (Yravedra, 2010). Despite these sites allowing the exploration of the access to animal resources by human groups during the Middle Pleistocene, all have been interpreted as sites where specific activities were carried out. Áridos 1 refers to an isolated elephant exploitation (Santonja et al., 1980; Santonja and Villa, 1990; Yravedra et al., 2010). Tafesa is an Acheulean site located next to a river course in which different animal species were exploited for some time (Baena and Baquedano, 2010; Yravedra et al., 2010). Only some few cut marks have been identified on remains of an aurouch and another possible one on proboscidean due to the poor preservation of the bone surfaces in Arriaga IIa, but what happened with the rest of the faunal sample of the site remains unexplained. The available information, therefore, does not allow us to specify the purpose of these occupations, whether they were limited to short time spans or match with longer stays.

The Estanque de Tormentas de Butarque (ETB-H02) site is located in the Complex Terrace of Butarque (CTB) in the Manzanares Valley -ETRS89 $40^{\circ} 20^{\prime} 18^{\prime \prime} \mathrm{N}, 3^{\circ} 39^{\prime} 57^{\prime \prime} \mathrm{W}$ at $582 \mathrm{~m}$ asl(Fig. 1; Álvarez Catalán et al., 2009; De los Arcos et al., 2008; 2010), which corresponds to the Middle Pleistocene from a biostratigraphic point of view (Laplana et al., 2015), matches with a MIS 6 or MIS 7 cold event (Blain et al., 2017a). This allows us to tackle the study of the human occupation in the Southern Meseta of Iberian Peninsula during the cold times of the Middle Pleistocene. Besides, ETB-H02 is one of the few open air Middle Pleistocene sites where not only has the lithic industry has been preserved, but also the faunal remains. In this paper, through the taphonomic and zooarchaeological analyses of ETB-H02, we will deal with the functionality analysis of the site located at the banks of the Manzanares River, with the purpose of contributing to the knowledge of the behaviour patterns of the human groups in the highlands of the Spanish Meseta during a cold climate event.

\section{The ETB-H02 site: geochronological and archaeological framework}

An important assemblage of faunal remains and lithic industry has been retrieved from an excavated area of $1029 \mathrm{~m}^{2}$ at ETB-HO2 (Álvarez Catalán et al., 2009; De los Arcos et al., 2008; 2010). This site is located to the right bank of the Manzanares river, downstream from Madrid city (Fig. 1). In this area, the fluvial system is affected by synsedimentary subsidence due to the karstic dissolution of the gypsum in the susbstrate, a well-known phenomenon in the large tertiary continental basins in Spain such as the Ebro basin (Benito et al., 1998, 2000), and also the nearby valley of the River
Jarama (Pérez-González, 1971). The main anomalous morphostratigraphical features that produce this type of subsidence includes a great thickening of fluvial deposits and superposition of the deposits correlative to different terrace levels, which can reach over 40 m (Pérez-González, 1971; Pérez-González et al., 2008). The terraces involved in the area which extends downstream from Madrid city are the youngest levels of the second half of the Middle Pleistocene, as well as those from the Late Pleistocene. All these terraces form the Complex Terraces of Butarque, hereafter CTB (Goy et al., 1989). Whereas upstream from the city of Madrid, over siliciclastic bedrock, thirteen levels of stepped alluvial terraces have been identified, $+4-5 \mathrm{~m}$ the lower and $+95 \mathrm{~m}$ the higher (PérezGonzález, 1994).

The construction of a storm water retention tank gave rise to the excavation of an area covering 7 ha in surface and with a $30 \mathrm{~m}$ maximum depth. Three stratigraphic sequences were identified in this hollow, from top to bottom named ETB 1, ETB 2 and ETB 3, plus a fourth basal sequence consisting of karstic remains and two fill in fill fluvial terraces of the Manzanares river at $+12 \mathrm{~m}$ and $+8-10 \mathrm{~m}$ (Domínguez-Alonso et al., 2009; Laplana et al., 2015; Blain et al., 2017a). Also, T $+12 \mathrm{~m}$ overlaps ETB 3, which is therefore older (Fig. 2a; Laplana et al., 2015). Four large units have been identified in ETB-H02, which is located next to the base of ETB 2 (Fig. 2b). From bottom to top, they are as follows (De los Arcos et al., 2008; 2010; Álvarez-Catalán et al., 2009):

\section{- Unit 1. Gravel and sand with faunal remains and lithic industry in a secondary position, judging by the high degree of rounding observed in both types of materials. \\ - Unit 2. Silty-sand up to $1 \mathrm{~m}$ thick, with faunal remains and lithic industry, and with interspersed sand lenses (Table 1). \\ - Unit 3. Clay up to $0.5 \mathrm{~m}$ thickness overlying Unit 1 and Unit 2, with plenty of faunal remains and lithic industry (Table 1 ). \\ - Unit 4. Sand and gravel with no archaeological remains.}

Two numerical dates were obtained by TL: $84.6+12.6 /-11.2 \mathrm{ka}$ and $74.9+10.2 /-9.2$ ka (Domínguez-Alonso et al., 2009, Fig. 3). However, the association of micromammals identified at the site suggests a Middle Pleistocene date (Laplana et al., 2015), therefore the TL dates are considered to be minimum ages. The evolutionary stage of Microtus brecciensis, together with the presence of Microtus arvalis, suggest that this site should be more recent than Valdocarros II in the valley of the Jarama river, which dates to the end of MIS 8 or early MIS 7 judging by the AAR (Panera et al., 2011) and ESR dates (Moreno et al. in this volume), and by the climatic demands of the herpetofauna (Blain et al., 2012). The association of amphibia and reptiles of ETB-H02 is consistent with the colder climatic conditions registered in the valleys of the Manzanares and Jarama rivers (Blain et al. in this volume). This suggests that the site could have been formed during the interstadial $7 d$ or MIS 6 . However, in PRERESA site Microtus cabrerae has been recorded, and Moreno et al. (in this volume) date this site to the early MIS 6 . Therefore, the evolutionary stage of Microtus brecciensis in ETB-H02 dates this site to a time earlier than PRERESA and later than Valdocarros II, which together with the climatic information given by the herpetofauna would point to the cold interstadial MIS 7d as the most probable chronological frame of the site.

A total of 2302 lithic pieces have been retrieved from ETB-H02, of which 1539 pieces were found in Unit 3 (De los Arcos et al., 2008). The lithic industry of these clay deposits does not show polishing nor rolling patina in $82 \%$ of the cases. Flint prevails among the raw materials. It could have been obtained from the gravel bars of the Manzanares river or from primary outcrops located in the interfluve of the Manzanares and Jarama rivers. Judging by the double patina of some flint pieces, they must have been used as 


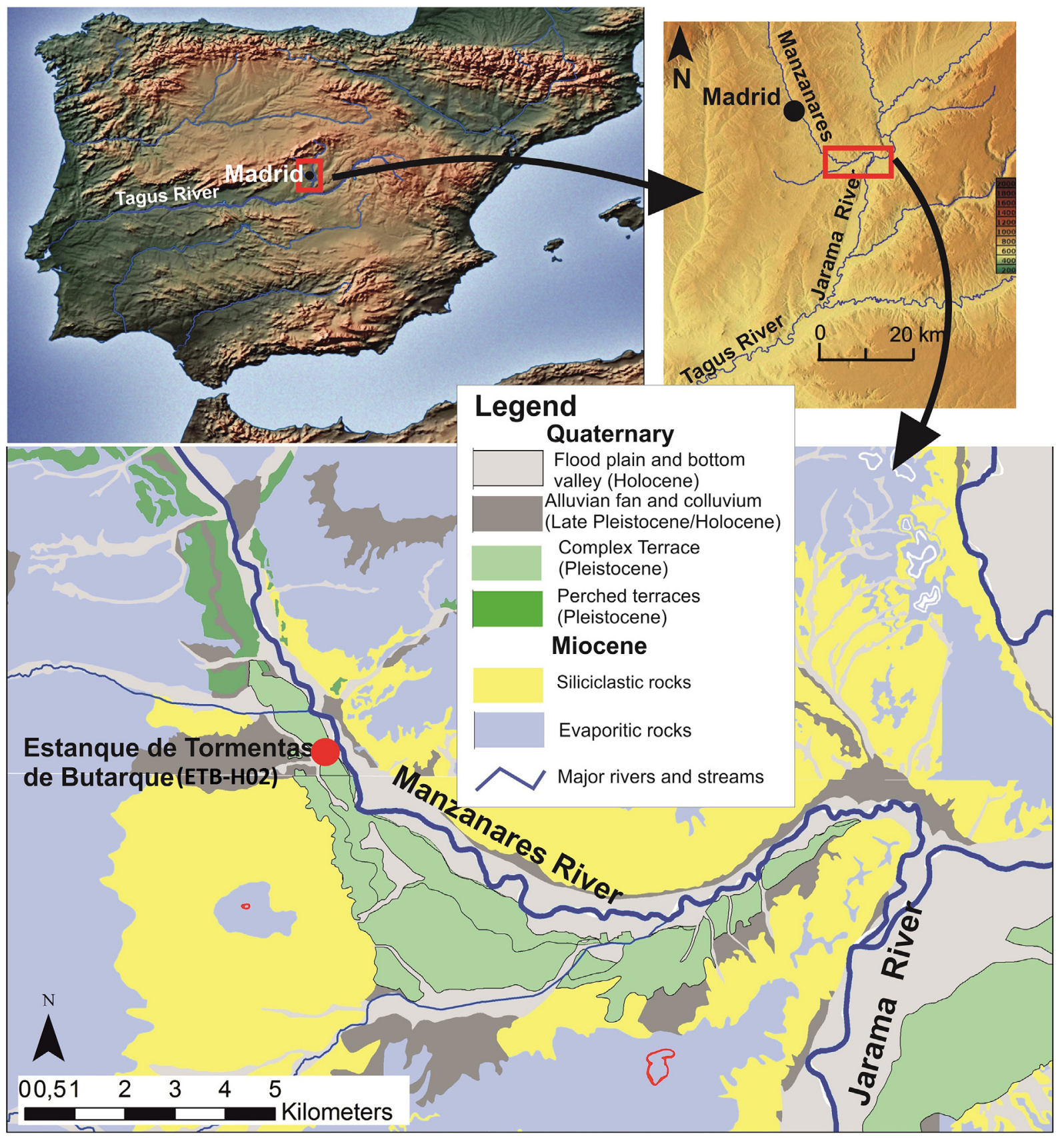

Fig. 1. Regional location of ETB- HO2 and view of the site.

support for knapped pieces prior to the occupation of ETB-H02. One of these pieces was the support of an undetermined core, on which four flakes could have been refitted. Only nine quartzite pieces have been found, including an ovoid biface and a core. This raw material is not found in the Manzanares deposits and could come from the discharges transported by the Jarama river, located to some $14 \mathrm{~km}$ (Panera, 2009). All phases of the operative chain are represented, therefore the carrying out of knapping activity can be inferred. Three main concentrations of knapping remains with pieces smaller than $1 \mathrm{~cm}$ have been recorded, in which nodules, cores, flakes, tools and macrotools have been identified (De los Arcos et al., 2008; 2010). The 26 cores identified were knapped with little elaborated operative schemes: unifacial, centripetal unifacial, bifacial, multifacial and on kombewa flake. Among the 30 retouched pieces recorded, retouched flakes prevail, followed by scrapers (30\%) and to a lesser extent denticulates (10\%). Just three bifaces have been recorded. These are flat and show well-balanced silhouettes, cordiform, amygdaloid and oval respectively (De los Arcos et al., 2008).

The paleoenvironmental information provided by Ruiz Zapata (Álvarez Catalán et al., 2009) suggests an open and dry environment, with Asteraceae, Chenopodiaceae, and Artemisia, which is consistent with the data provided by the herpetofauna, micromammals and macromammals. These point to harsh steppe conditions, with mammals well adapted to open spaces (Laplana et al., 2015; Blain et al. in this volume). Thus, the mammals identified in this site are: Stephanorhinus sp., Equus ferus, Equus hydruntinus, Bos primigenius, Cervus elaphus, Sus scrofa, E. (Palaeoloxodon) antiquus, 


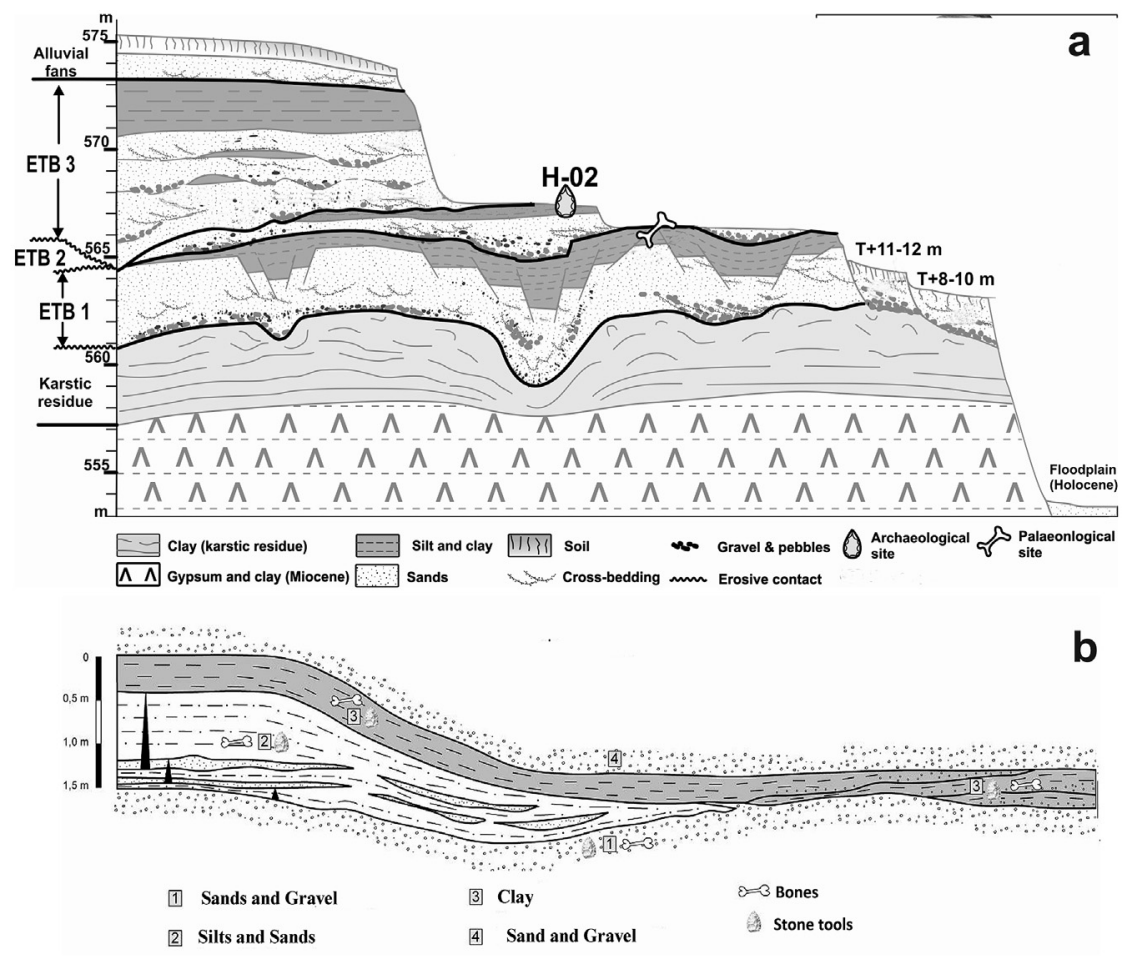

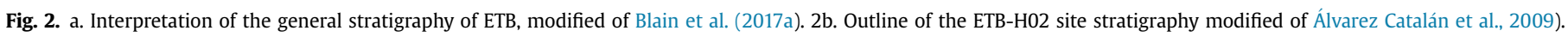

Table 1

NISP representation of the ETB-H02 sample.

\begin{tabular}{|c|c|c|c|c|c|c|c|c|c|c|}
\hline \multirow[t]{2}{*}{ NISP } & \multicolumn{3}{|c|}{ Unit 2} & \multicolumn{6}{|c|}{ Unit 3} & \multirow[b]{2}{*}{ Total } \\
\hline & LA1 & LA2 & LA3 & 2 & 3.1 & 3.2 & 3 & 4 & 6 & \\
\hline E. (Palaeoloxodon) antiquus & 2 & 6 & & & & & 1 & & & 9 \\
\hline Stephanorhinus sp. & & 1 & & & & & & & & 1 \\
\hline Bison priscus & & & & & & 9 & & & & 9 \\
\hline Bos primigenius & & 1 & & & & 9 & 45 & 13 & 1 & 69 \\
\hline Bos/Bison & & & & & & 4 & 6 & 2 & 2 & 14 \\
\hline Equus hydruntinus & & & & & & 3 & 1 & & & 4 \\
\hline Equus ferus & & 1 & & 1 & & & 48 & 19 & 1 & 70 \\
\hline Cervus elaphus & & 3 & 2 & 1 & & 15 & 49 & 10 & 2 & 82 \\
\hline Sus scrofa & & & & & & & 29 & 2 & & 31 \\
\hline Canis lupus & & & & & & & 6 & 1 & & 7 \\
\hline Very Large (Size 5-6) & 1 & 2 & & & & & & & & 3 \\
\hline Large (Size 4) & 11 & 5 & 8 & & 2 & 23 & 65 & 54 & 1 & 169 \\
\hline Medium (size $3 b$ ) & 5 & & 2 & & & 2 & 43 & 27 & & 79 \\
\hline Medium (size 3a) & 1 & 2 & & & & 3 & 33 & 10 & & 49 \\
\hline Small (size 2) & & & & 1 & & & 16 & 1 & & 18 \\
\hline Small (size 1) & & & & & & & 14 & 5 & & 19 \\
\hline Indet & 2 & 3 & 1 & 2 & & 44 & 164 & 97 & 1 & 314 \\
\hline Total & 22 & 24 & 13 & 5 & 2 & 112 & 520 & 241 & 8 & 947 \\
\hline
\end{tabular}

Bison priscus and Canis lupus, among the macrovertebrates; and Crocidura cf., C. russula, Allocricetus bursae, Arvicola aff., A. sapidus, Microtus brecciensis, Apodemus sylvaticus, Eliomys quercinus, Oryctolagus cf., O. cuniculus, Erinaceus sp, Microtus arvalis and Lepus sp. among the microvertebrates (Laplana et al., 2015).

\section{Sample and methods}

947 remains of macromammals associated with Units 2 and 3 have been recorded in ETB-H02 (Fig. 2b). The majority of the analysed material comes from Unit 3, which is subdivided into several levels. Of those, sub-level 3 is the most representative, providing more than $50 \%$ of the fossil sample of the site, together with level 4 .
For that reason, the study presented in this paper will focus on units 2 and 3.

Taxonomic identifications were based principally on teeth and reference material. However, in those cases when such determination was not possible, fragments were attributed to animal weight/size classes following Bunn (1982), where "small-sized" refers to sizes 1 and 2, "medium-sized" to size 3, "large" to sizes 4-5 and extra large refers to size 6.

Quantification of faunal remains was grouped by NISP (Number of Identifiable Specimen), MNE (Minimum Number of Element) and MNI (Minimum Number of Individuals). MNE includes limb shafts, age, size, and biometrics. Elements were quantified according to Yravedra and Domínguez-Rodrigo (2009). Following Barba and 

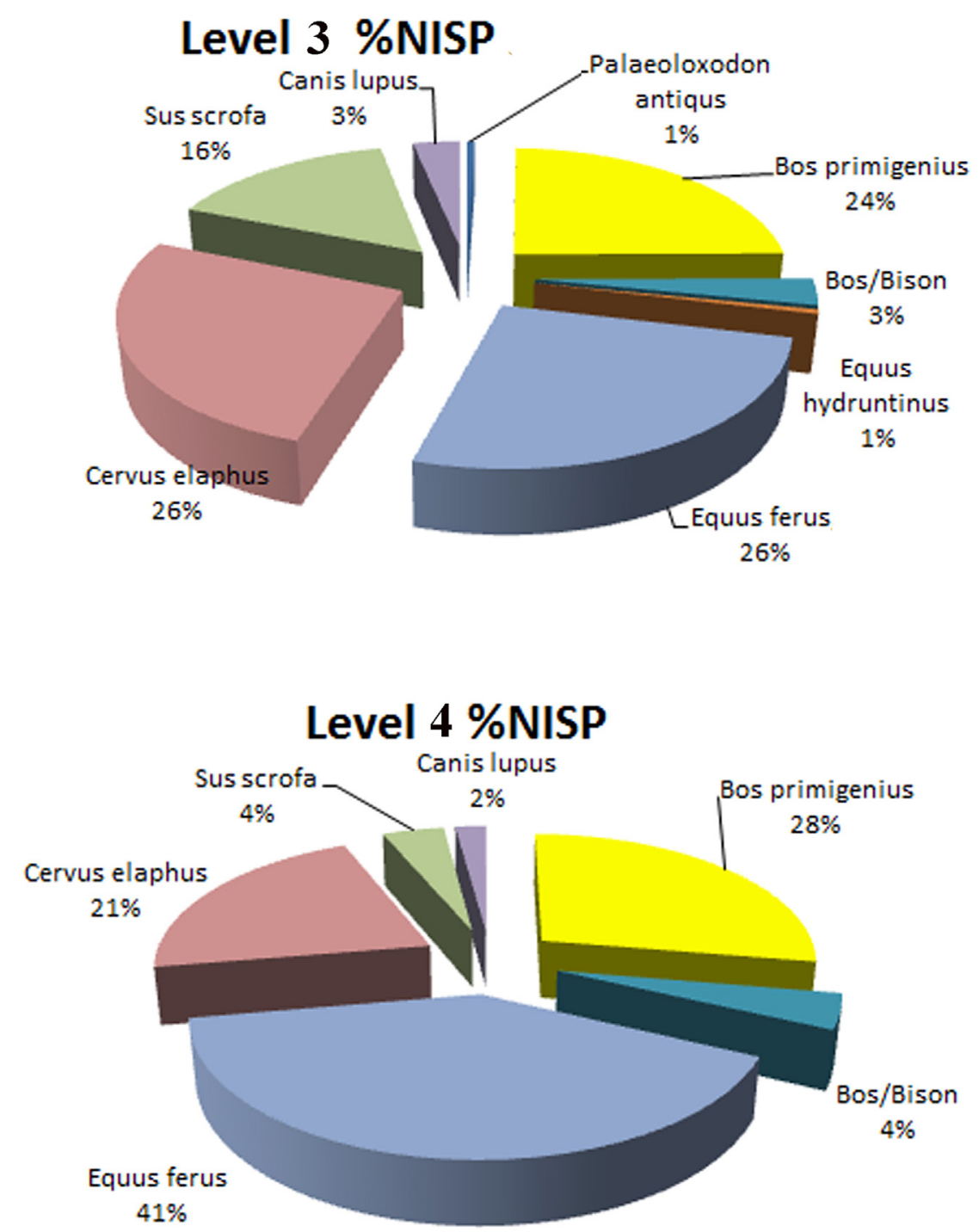

Fig. 3. Percentage representation of the macromammals remains recorded in sub-levels 3 and 4 .

Domínguez-Rodrigo (2005), factors such as shaft thickness, section shape, and medullar surface properties were considered for limb bone identifications. MNI estimates considered element side and ontogenetic age (Brain, 1969). To assess mortality patterns, specimens were assigned to one of three categories based on tooth eruption and crown wear: infantile, juvenile-prime adult, and adult.

Skeletal part profiles were organized into four anatomical regions: cranial (i.e. horn, cranium, mandible and teeth), axial (vertebrae, ribs, pelvis and scapula, sensu Yravedra and DomínguezRodrigo, 2009), upper appendicular elements (humerus, radius, ulna, femur, patella, and tibia) and lower appendicular elements (metapodial, carpals, tarsals, phalanges, and sesamoids). Long limb bones were further divided into upper (humerus and femur), intermediate (radius and tibia), and lower (metapodial) bones (Domínguez-Rodrigo, 1997).

In order to reconstruct site formation processes, assess site integrity, and evaluate the contribution of various biogenic agents to the faunal assemblage, several procedures were followed. Bone fragmentation was analysed according to three variables: firstly, bones were divided into several categories according to their length: $<3,3-5,5-10 \mathrm{~cm}$ and $>10 \mathrm{~cm}$; secondly, the percentage of partial representation of specimen was analysed. Type 1 refers to specimens $<50 \%$ of length; type 2 to specimens with $>50 \%$ of total length; and type 3 to complete specimens. Finally, shaft preservation was classified following Bunn's (1982) circumference types, where type 1 refers to specimens with $<50 \%$ of the shaft circumference intact, type 2 to specimens with $>50 \%$ of the shaft circumference intact, and type 3 to specimens with an intact shaft circumference.

The impact of water activity was estimated with fragment size distributions and the presence of abrasion, polishing, rounded bones, and carbonates (Voorhies, 1969). Signs of polishing, rounding or abrasion would be expected in transported assemblages, but also in non-transported assemblages exposed to water currents and mobile sediments, such as those encased in sand matrix (Thompson et al., 2011). Determining whether or not the assemblage is in primary versus secondary position is particularly important given the fluvial depositional context of the site.

Weathering was analysed following Behrensmeyer (1978). A 
high degree of weathering can affect the fragmentation and deterioration of bones. It is important to distinguish whether weathering alterations are affecting bones showing green and/or dry (including diagenetic) fracture patterns. To identify both types of breakage we followed criteria according to Villa and Mahieu (1991). Dry breaks result in abundant breaks that are longitudinal and/or transverse to the axis of the bone and breakage planes that are uneven, rough, and possess micro-step fractures. Dry breaks are also characterized by cortical medullary surface angles that are close to $90^{\circ}$. In contrast, green-broken specimens frequently have smoother surfaces and more abundant oblique breakage planes.

Moreover, a systematic search for bone surface modifications was carried out with $10 \mathrm{x}-20 \mathrm{x}$ hand lenses (following Blumenschine, 1995). Diagnostic criteria defined by DomínguezRodrigo et al. (2009) guided the identification of cut marks, whereas tooth and percussion marks were recorded following Blumenschine $(1988,1995)$. Modifications are analysed by element type and bone section based on NISP values according to Domínguez-Rodrigo (1997) and Barba and Domínguez-Rodrigo (2005). The presence of tooth, percussion and cut marks is recorded for the whole of the remains, although estimated percentages include only well-preserved postcranial bone surfaces.

\section{Results}

The bone sample of ETB-H02 has been divided into two large units. The first one, Unit 2, consists of a sandy-silt sedimentary matrix, and provides a little representative fossil sample of 59 remains shared in sub-levels LA1, LA2 and LA3 (Table 1). Large size taxa prevail in these levels, such as E. (Palaeoloxodon) antiquus, Stephanorhinus sp., undetermined bones of size 4 animals, horse and deer. None of these species is represented by more than one individual and all of them are adults (Table 2).

Unit 3 consists of clay deposits (sub-levels 3 and 4) that alternate with sandy sub-levels (sub-levels 2, 3.1, 3.2, 6). Sub-level 3 of Unit 3 contains more than $50 \%$ of the total site assemblage (Table 1 ), whereas sub-levels 2, 3.1, 3.2 and 6 barely provide any remains, and the identified taxa are already represented in sub-level 3, except for Bison, which is only present in sub-level 3.2 (Table 1 ).

A diversified pattern can be observed in sub-levels 3 and 4 (Fig. 3), with equids, bovines and cervides represented in a balanced way. NISP of sub-level 4 suggests that horse is better represented than cervides and bovines, however all of them have the same MNI (Table 2). With regard to the mortality patterns, all are adults, except for a juvenile bison individual from sub-level 3.2 and an equid and a bovine from sub-level 3.

Taking into consideration the low number of documented individuals, and that more than $1000 \mathrm{~m}^{2}$ have been excavated, the faunal spectrum is little representative. On the other hand, the MNI

Table 2

MNI representation of the ETB-H02 sample. This sign* indicates that one of the represented individuals is a juvenile.

\begin{tabular}{|c|c|c|c|c|c|c|c|c|c|c|}
\hline \multirow[t]{2}{*}{ MNI } & \multicolumn{3}{|c|}{ Unit 2} & \multicolumn{6}{|c|}{ Unit 3} & \multirow[b]{2}{*}{ Total } \\
\hline & LA1 & LA2 & LA3 & 2 & 3.1 & 3.2 & 3 & 4 & 6 & \\
\hline E. (Palaeoloxodon) antiquus & 1 & 1 & & & & & 1 & & & 3 \\
\hline Stephanorhinus sp. & & 1 & & & & & & & & 1 \\
\hline Bison priscus & & & & & & $1^{*}$ & & & & 1 \\
\hline Bos primigenius & & 1 & & & & 1 & $2^{*}$ & 1 & 1 & 6 \\
\hline Equus hydruntinus & & & & & & 1 & 1 & & & 2 \\
\hline Equus ferus & & 1 & & 1 & & & $2^{*}$ & 1 & 1 & 6 \\
\hline Cervus elaphus & & 1 & 1 & 1 & & 1 & 2 & 1 & 1 & 8 \\
\hline Sus scrofa & & & & & & & 1 & 1 & & 2 \\
\hline Canis lupus & & & & & & & 1 & 1 & & 2 \\
\hline
\end{tabular}

is low, as no taxon shows more than ten individuals.

The skeletal profiles of the less representative levels are characterized by the prevalence of cranial elements. Thus, in LA1-3 all the elements of rhino and elephant are cranial except a fragment of radius of rhino and an elephant metapodial. The remaining animals show a similar pattern, although bones of all the anatomical sections are present, as vertebrae fragments and long bones of size 3 and 4 animals. In any case, such a small sample does not allow many conclusions.

Sub-levels 3 and 4 of Unit 3, those with the greatest amount of remains, do not show particularly representative patterns either. None of the groups of species, except those of size 3 of sub-level 3 , is represented by more than 100 elements (Table 3 ).

Bones with lesser density, such as vertebrae and ribs, and compact bones, such as carpals and tarsals, are quite abundant. Therefore, the faunal assemblage of ETB-H02 is not determined by buoyancy. As has been proved by Voorhies (1969), those bones are more prone to be transported by water currents. Besides, bones more resistant to water transport, such as jaws, are not represented, which suggests that this anatomical bias is not due to water currents.

The bone remains from ETB-H02 show a low intensity fracture pattern. Complete or nearly complete bones are represented in all sub-levels, and more than $20 \%$ of them are longer than $5 \mathrm{~cm}$ (Table 4). Many long bones show a wide circumference index and length in relation to the complete length of the bone and its circumference measurement (Table 5). In several cases dry fragmentation has been recorded, which suggests post-depositional breakage as a consequence of the sedimentary pressure or other diagenetic processes (Table 6). Of the bone elements identified to skeletal level or species none is smaller than $3 \mathrm{~cm}$, whereas $71 \%$ of the undetermined remains are under this threshold. Identification of the remains is therefore conditional to their fragmentation.

The analysis of the bone surfaces shows that preservation conditions are different depending on the sub-levels (Table 7). Levels with sandy matrices (LA1, LA 2 and LA 3 of unit 2, and sub-levels 2, 3.1 and 6 of unit 3) show a higher degree of water alterations, over $50 \%$ of the remains in all cases (Table 7 ), which implies a greater

Table 3

Skeletal profiles of the most representative sub-levels 3 and 4 in unit 3.

\begin{tabular}{|c|c|c|c|c|c|c|}
\hline \multirow[t]{2}{*}{ MNE } & \multicolumn{3}{|c|}{ Sub-level 3} & \multicolumn{3}{|c|}{ Sub-level 4} \\
\hline & size 4 & size 3 & size $1-2$ & size 4 & size 3 & size 2 \\
\hline Cranial & 1 & 2 & & 1 & 1 & \\
\hline Maxillar & 1 & & & & & \\
\hline Mandible & 2 & 3 & & & 2 & \\
\hline Teeth & 28 & 49 & & 1 & 3 & \\
\hline Vertebrae & 8 & 34 & 16 & 6 & 4 & \\
\hline Rib & 8 & 23 & 17 & 1 & 1 & \\
\hline Scapulae & 1 & & & & & \\
\hline Pelvis & 1 & 1 & & 1 & & \\
\hline Humerus & 1 & 2 & 1 & 1 & 1 & \\
\hline Radius & & & 1 & & 1 & \\
\hline Ulna & & 1 & 1 & 1 & 1 & \\
\hline Femur & 2 & 2 & & 1 & 1 & 2 \\
\hline Tibia & & 2 & & 1 & 2 & 1 \\
\hline Metapodial & 2 & & & 3 & 4 & \\
\hline Patella & 1 & 4 & & & & \\
\hline Carpal-Tarsal & 1 & 14 & 1 & 2 & 10 & \\
\hline Phalange & & 3 & & & 2 & \\
\hline Sesamoid & & 1 & & 1 & & \\
\hline Total & 57 & 141 & 37 & 20 & 33 & 3 \\
\hline Cranieal & 32 & 54 & 0 & 2 & 6 & 0 \\
\hline Axial & 18 & 58 & 33 & 8 & 5 & 0 \\
\hline Upper Limbs & 3 & 7 & 3 & 4 & 6 & 3 \\
\hline Lower Limbs & 4 & 22 & 1 & 6 & 16 & 0 \\
\hline
\end{tabular}


Table 4

Measurements of the bone fragments found in ETB-H02.

\begin{tabular}{llllll}
\hline \multirow{2}{*}{ Unit } & Sub-level & \multicolumn{2}{l}{$\%$ de NISP } & & \\
\cline { 3 - 6 } & & $<3 \mathrm{~cm}$ & $3,1-5 \mathrm{~cm}$ & $5,1-10 \mathrm{~cm}$ & $>10 \mathrm{~cm}$ \\
\hline 3 & 2 & 40 & 40 & & 20 \\
& 3 & 57 & 19 & 16 & 8 \\
& 3.1 & & & 100 & \\
& 3.2 & 66 & & 19 & 15 \\
& 4 & 67 & 16 & 9 & 13 \\
& 62 & 62 & & 25 & 9 \\
& 6 & 46 & 32 & 13 & 23 \\
& LA1 & 18 & 18 & 41 & 22 \\
\hline
\end{tabular}

Table 5

Analysis of circumference degree on long bones and their length in relation to the total length of the bone, according to Bunn (1982) criteria.

\begin{tabular}{|c|c|c|c|c|c|}
\hline \multirow[b]{2}{*}{ Sub-level } & \multicolumn{3}{|c|}{ Unit 3} & \multicolumn{2}{|c|}{ Unit 2} \\
\hline & 3 & 3.2 & 4 & LA2 & LA3 \\
\hline \multicolumn{6}{|c|}{ \% NISP Circumference degree } \\
\hline I & 75 & 33 & 66 & 100 & 100 \\
\hline $\mathrm{C}$ & & & 3 & & \\
\hline $\mathrm{O}$ & 25 & 67 & 31 & & \\
\hline \multicolumn{6}{|c|}{ \% NISP Length in relation to complete bone } \\
\hline$<50 \%$ & 72 & & 80 & 100 & 100 \\
\hline$>50 \%$ & 28 & & 17 & & \\
\hline Complete & & 100 & 3 & & \\
\hline
\end{tabular}

Table 6

Account of fracture types on long bones: green, dry and undetermined pattern.

\begin{tabular}{lllll}
\hline \multirow{2}{*}{ Unit } & Sub-level & \multicolumn{4}{l}{ Fragmentation pattern for large bones } \\
\cline { 3 - 5 } & & \% Green & \% Dry & \% Indet \\
\hline 3 & 2 & 33.3 & 33.3 & 33.3 \\
& 3 & 33 & 36 & 31 \\
& 3.2 & & 18 & 82 \\
& 4 & 27 & 40 & 33 \\
& 6 & & & 100 \\
& LA1 & 72 & 14 & 14 \\
& LA2 & 25 & 75 & \\
\hline
\end{tabular}

number of remains with bad preservation of the bone surface. On the contrary, sub-levels with clayish matrices, such as 3 and 4 , show a lower degree of water alteration. This is outstanding in sub-level 3 , as only $25 \%$ of the bones show some type of water alteration. With regard to this type of alteration, bones with slight or moderate abrasion, polishing and rounding have been observed, and except for isolated cases, bones with a high degree of water alteration have not been found. These parameters are comparable with what was observed in the skeletal profiles, where less dense elements that would be easily transported by currents were abundant (Voorhies, 1969). Therefore, water did not transport elements, but altered part of the bone surfaces through polishing, abrasion and edge rounding, as has been proposed by Thompson et al. (2011).

Considering the scarce number of long bones showing signs of weathering, the bones were probably quickly buried. The abundance of bones stained with manganese suggests that this precipitated under low energy and at least partially waterlogged conditions, which would be consistent with what has been observed in the water alterations analysis. Sub-levels 3 and 4, which are associated with clay deposits, are the ones that show more evidence regarding this type of alteration. These waterlogged conditions could explain why some anatomical elements, long bones and axial elements are complete, with no signs of carnivore activity. Likewise, this waterlogging would also explain the low impact of biochemical alterations (Table 7).

The action of carnivores is very low. Only some bones from sublevels 3.2, 3, 4 and 6 of unit 3 show some tooth marks, in any case smaller than $2 \mathrm{~mm}$. This suggests that the carnivore involved would be of small size, like a fox, and that it played a secondary role. Other evidence supporting the low impact of carnivores over the fossil assemblage is that there are quite a lot of appendicular and complete axial elements with no evidence of scavenging, and that the percentage of epiphyses is quite high (Table 8). Nevertheless, despite the low action of carnivores, carcasses were equally spread by them, giving rise to certain bias, which has been identified.

Human activity has barely left any evidence of burnt bones $(\mathrm{NISP}=8)$, nor bones with percussion marks $(\mathrm{NISP}=1)$. There are examples with cut marks, although scarcely represented (Table 7). Equids, bovines and cervides show cut marks in sub-levels 3, 3.2 y 4 (Table 9). Most of those marks are associated with defleshing and disarticulating processes, although in some cases skinning marks have been identified on a skull (Fig. 4).

With regard to the spatial analysis of the remains, a conclusive association showing concentrations of lithic industry associated with bones with cut marks has not been observed, and therefore specific filleting areas could not be established. However, certain activity areas associated with specific agents have been established. A small area associated with bones with cut marks, in which equids, bovines and a deer show signs of human activity has been observed (Fig. 4, blue area); also, another area in which bones appear concentrated with no evidence of human intervention, but of carnivores (red area); finally, an area with unaltered complete bones.

\section{Discussion and conclusion}

ETB-H02 is a Middle Pleistocene site with a complex taphonomic history. Several stratigraphic levels with archaeological materials have been excavated in an area of $1029 \mathrm{~m}^{2}$. Of those, only sub-levels 3 and 4 of unit 3 have provided an amount of remains which allows a hypothesis with regard to the formation processes of the recorded faunal and lithic industry assemblages. With regard to the remaining levels, although there are some faunal remains with cut marks (Table 9), most of the preserved bone remains do not show conspicuous signs of human activity. There are a substantial percentage of remains with water alterations and where dry breakage pattern does prevail.

In the most representative levels, 3 and 4 , human presence is identified not only by lithic knapping, but also by cut marks present in aurouchs, horses, wild donkeys and deer. Spatially, some areas of intervention on individuals of different species of mammals have been distinguished in sub-level 3 (Fig. 4). The human activity recorded, however, does not allow the consideration of the human groups as the only ones responsible for the faunal accumulation. The presence of bones complete and in anatomical position, with no variations due to carnivores or humans, suggests that some individuals died of natural causes, their remains covered with water and later buried in a short time span. It must also be taken into consideration that, although bones slightly modified by carnivores have been recorded, these animals are able to produce significant alterations on the fossil record. Therefore, the identified processes of natural death explain, at least partially, the fossil accumulation of the site. With regard to the individuals on which human activity has been identified, the human groups could have acted on corpses of mammals that died of natural causes on site, or could have transported carcasses of mammals obtained in other areas due to some advantage in the location of the site.

The lack of significant accumulations of faunal remains does not 
Table 7

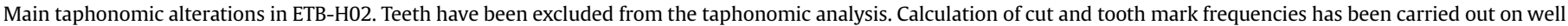
preserved NISP. All water alteration includes bones with any kind of water alteration.

\begin{tabular}{|c|c|c|c|c|c|c|c|c|c|c|c|c|c|}
\hline Sub-level & NISP & Bad Surface & $\%$ & Diagenetic & $\%$ & All water alterations & $\%$ & Rounded & $\%$ & Abrasion & $\%$ & Polishing & $\%$ \\
\hline LA1 & 22 & 12 & 55 & 2 & 9 & 13 & 59 & 3 & 14 & 13 & 59 & 3 & 14 \\
\hline LA2 & 22 & 9 & 41 & 2 & 9 & 11 & 50 & 9 & 41 & 10 & 45 & 9 & 41 \\
\hline LA3 & 11 & 5 & 45 & 1 & 9 & 3 & 27 & 1 & 9 & 3 & 27 & 4 & 36 \\
\hline 2 & 5 & 3 & 60 & & & 5 & 100 & 2 & 40 & 3 & 60 & 1 & 20 \\
\hline 3.1 & 2 & 2 & 100 & & & 2 & 100 & 2 & 100 & 1 & 50 & 2 & 100 \\
\hline 3.2 & 98 & 41 & 42 & & & 44 & 45 & 37 & 38 & 31 & 32 & 14 & 14 \\
\hline 3 & 435 & 128 & 29 & 2 & & 107 & 25 & 61 & 14 & 67 & 15 & 98 & 23 \\
\hline 4 & 234 & 110 & 47 & 11 & 5 & 94 & 40 & 65 & 28 & 57 & 24 & 51 & 22 \\
\hline 6 & 4 & 2 & 50 & & & 4 & 100 & 2 & 50 & 3 & 75 & 3 & 75 \\
\hline \multirow[t]{2}{*}{ Total } & 833 & 312 & 37 & 18 & 2 & 283 & 34 & 227 & 27 & 188 & 23 & 183 & 22 \\
\hline & NISP & Manganese & $\%$ & Biochemical & $\%$ & Weathering & $\%$ & Trampling & $\%$ & Cut mark & $\%$ & Tooth mark & $\%$ \\
\hline LA1 & 22 & 9 & 41 & 1 & 5 & 5 & 23 & & & 1 & 10 & & \\
\hline LA2 & 22 & 3 & 14 & 1 & 5 & 4 & 18 & 2 & 9 & 1 & 8 & & \\
\hline LA3 & 11 & 5 & 45 & 1 & 9 & 1 & 9 & & & & & & \\
\hline 2 & 5 & 2 & 40 & 1 & 20 & & & & & & & & \\
\hline 3.1 & 2 & 2 & 100 & & & & & & & & & & \\
\hline 3.2 & 98 & 55 & 56 & & & 3 & 3 & 1 & 1 & 1 & 2 & 4 & 7 \\
\hline 3 & 435 & 332 & 76 & 3 & 1 & 4 & 1 & 16 & 4 & 7 & 2 & 9 & 3 \\
\hline 4 & 234 & 90 & 38 & 11 & 5 & 3 & 1 & 7 & 3 & 5 & 4 & 3 & 2 \\
\hline 6 & 4 & 1 & 25 & & & & & & & & & 1 & 50 \\
\hline Total & 833 & 499 & 60 & 18 & 2 & 20 & 2 & & & & & 17 & 3 \\
\hline
\end{tabular}

Table 8

Representation of appendicular bones by sections, including epiphyses and diaphysis in NISP.

\begin{tabular}{lllllll}
\hline Unit & Sub-level & Complete & Shaft & Ep. Dist & Ep. Prox & Total \\
\hline 3 & 3 & 2 & 11 & 4 & 2 & 19 \\
& 3.2 & 3 & & & & 3 \\
& 4 & 1 & 12 & 12 & 4 & 29 \\
2 & LA2 & & 4 & 1 & & 5 \\
& LA3 & & & 1 & & 1 \\
& Total & 6 & 27 & 18 & 6 & 57 \\
\hline
\end{tabular}

allow the interpretation of the site as a base camp or a reference place, although it can be asserted that at least from time to time human groups attended to the site in order to acquire or process carcasses. Cut marks are related to muscular bundles, suggesting that the processed animals were hunted, or at least that there was an early access to the corpses in the surroundings or at site. It can be inferred from the available information that at least isolated human occupations occurred at ETB-H02, during which lithic tools were manufactured and different individuals of different species of large mammals were processed. The lithic record shows abundant flakes and lithic remains, and suggests that knapping activity could have been associated with carcasses processing. This hypothesis cannot be confirmed until the techno-morphological, functional and traceologic analyses of the lithic industry are finished.

The peopling of northwest Europe prior to MIS 13 is reduced to mild areas and climatic periods, however from this time on, there are signs of human occupations during interglacial periods and cold areas (Cohen et al., 2012). The use of fire could have played an important role some time after 300-400 Ka (Roebroeks and Villa, 2011). Nevertheless, the human occupation is more frequent during mild events of MIS 7 and MIS 5 (Roebroeks et al., 1992; Brauer et al., 2007; Hublin and Roebroeks, 2009; Egeland et al., 2014). Human occupation during MIS 7 is well recorded in England, northern Germany and northern France, and continues in MIS 6, although to a lesser intensity. An increment of sites is confirmed during this period in southwest France. This suggests the hypothesis that this region could have worked as shelter during the harshest times (Daujeard et al., 2012; Hérisson et al., 2016). Therefore, although from MIS 7 on human groups in Europe could have been better adapted to cold climatic conditions, southwest France and the Iberian Peninsula constituted shelter areas (Jochim, 1987; Stewart and Stringer, 2012).

Peopling of the highlands of the interior lands of the Iberian Peninsula during cold climatic events of the Late Pleistocene is well recorded (Cacho et al., 2016; Yravedra et al., 2016; Alcaraz et al., 2017). However, the number of Middle Pleistocene sites in which a significant difference of the mean annual temperature (MAT) with regard to current temperatures could be stated is very low. A harsher climate has been suggested for the Middle Stratigraphic Complex de Ambrona (MIS 11, Santonja and Pérez-González, 2005), $1140 \mathrm{~m}$ a.s.l., than for the Lower Stratigraphic Complex (Santonja et al., 2014b), for which a similar MAT to the current one has been estimated (Blain et al., 2015). In Cuesta de la Bajada (MIS 9/8, Santonja et al., 2014a), $920 \mathrm{~m}$ a.s.l., it has been described a MAT $2.5^{\circ} \mathrm{C}$ lower than currently, and its addition to MIS 9b or late MIS 8 has been proposed (Blain et al., 2017b). In level 2 of Valdocarros II

Table 9

Percentage representation of cut marks (CM) and tooth marks (TM) in ETB-H02.

\begin{tabular}{|c|c|c|c|c|c|c|c|c|c|c|c|c|c|c|c|c|}
\hline \multirow[b]{2}{*}{ Sub-level } & \multicolumn{2}{|l|}{ Bos } & \multirow{2}{*}{$\frac{\text { E. hy }}{\% \mathrm{CM}}$} & \multicolumn{2}{|c|}{ Cervus } & \multirow{2}{*}{$\frac{\text { E. fer }}{\% \mathrm{CM}}$} & \multirow{2}{*}{$\frac{\text { Sus }}{\% \mathrm{TM}}$} & \multicolumn{2}{|c|}{ Undet Size 4} & \multicolumn{2}{|c|}{ Undet Size 3b } & \multicolumn{2}{|c|}{ Undet Size 3} & \multicolumn{2}{|c|}{ Undet Size 2} & \multirow{2}{*}{$\frac{\text { Undet Size } 1}{\% \mathrm{TM}}$} \\
\hline & $\% \mathrm{CM}$ & $\% \mathrm{TM}$ & & $\% \mathrm{CM}$ & $\% \mathrm{TM}$ & & & $\% \mathrm{CM}$ & $\% \mathrm{TM}$ & $\% \mathrm{CM}$ & $\% \mathrm{TM}$ & $\% \mathrm{CM}$ & $\% \mathrm{TM}$ & $\% \mathrm{CM}$ & $\% \mathrm{TM}$ & \\
\hline 3 & 13 & 4,2 & & 33 & & 5 & 4,3 & 3 & 6 & & & 5 & 5 & 6 & 6 & 36 \\
\hline 3.2 & & & 50 & & & & & & & & & & & & & \\
\hline 4 & 9 & & & & 20 & 12 & & 3 & 3 & 9 & 9 & & & & & \\
\hline 6 & & & & & & & & & 100 & & & & & & & \\
\hline LA1 & & & & & & & & & & 100 & & & & & & \\
\hline
\end{tabular}




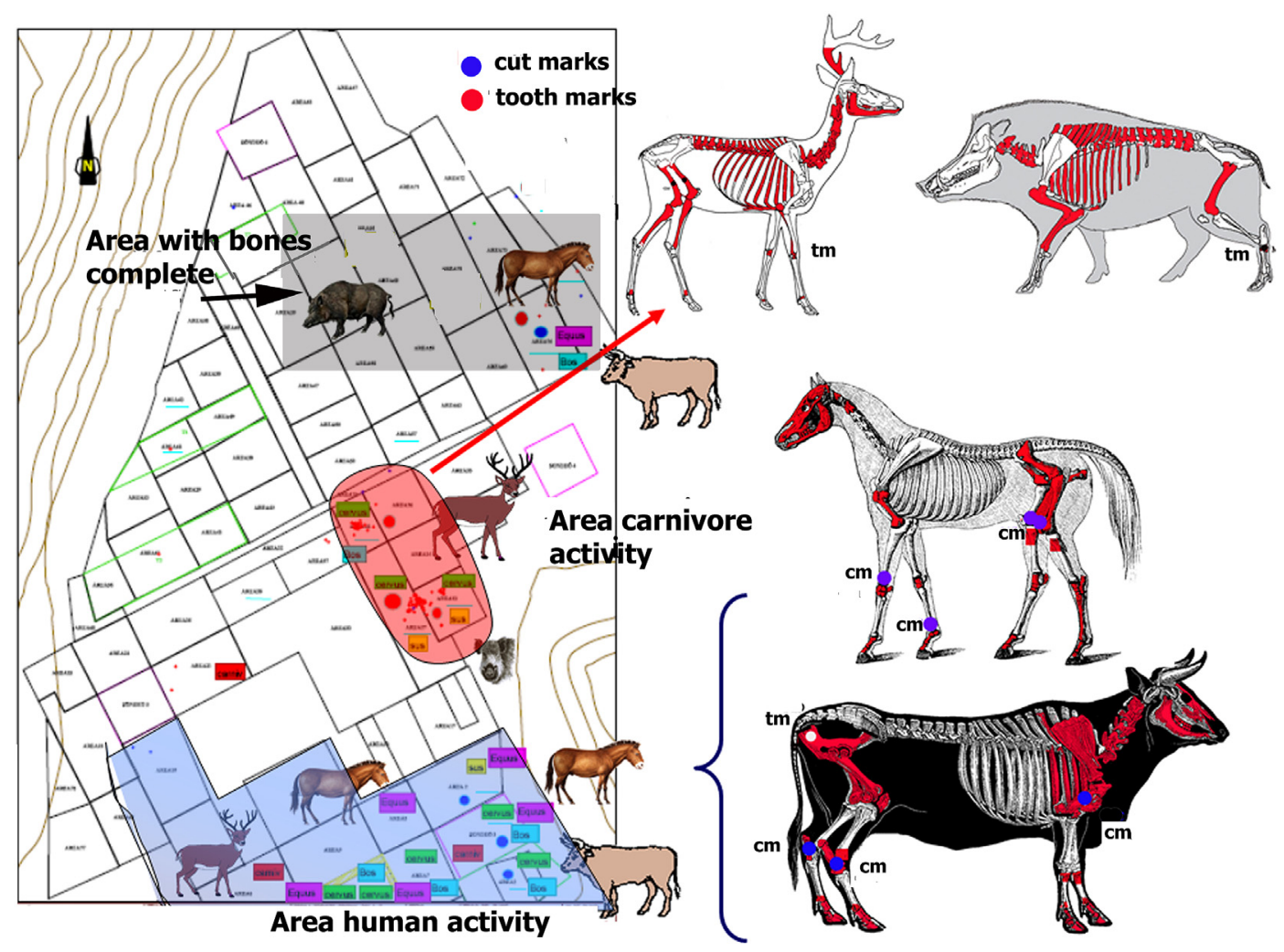

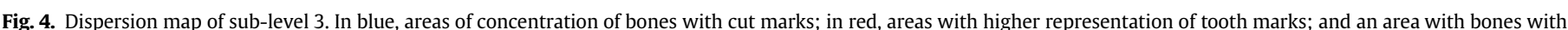

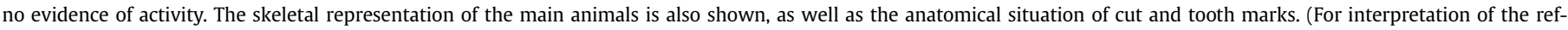
erences to colour in this figure legend, the reader is referred to the Web version of this article.)

(MIS 8/7, Panera et al., 2011), $554 \mathrm{~m}$ a.s.l., a MAT $1.8^{\circ} \mathrm{C}$ lower than the current has been inferred, and it has been proposed as an addition to the late MIS 8 (Blain et al., 2012). ETB-H02, $582 \mathrm{~m}$ a.s.l., is the Middle Pleistocene site with the lowest MAT compared to the current one, $-3{ }^{\circ} \mathrm{C}$ (Blain et al., 2017a), for which its addition to MIS $7 \mathrm{~d}$ is proposed, according to the evolutionary stage of Microtus brecciensis (Laplana et al., 2015) and the chronology of PRERESA (Moreno et al. in this volume).

In conclusion, ETB-HO2 reinforces the thesis that the continental climate and the height of the interior of the Iberian Peninsula were no obstacle for its occupation during the cold climatic times of the Middle Pleistocene. Also, in ETB-H02, a recurrent occupation is suggested, as faunal remains have been identified in different levels and sub-levels. This is unlikely in other sites at MJV, such as Áridos 1 and 2 (Santonja et al., 1980; Yravedra et al., 2010) and Arriaga IIa (Rus and Vega, 1984), which represent isolated occupations related to the processing of elephant carcasses.

\section{Acknowledgements}

We would like to thank to Área Sociedad Cooperativa for allowing us access to study the faunal remains retrieved from the ETB-H02 site, as well as to Carlos Gil, Saleta de los Arcos, Raquel Martín Muñoz and Yolanda Corchado for their help during the archaeological excavation. The manuscript was improved by the comments of two anonymous reviewers.

\section{Appendix A. Supplementary data}

Supplementary data related to this article can be found at https://doi.org/10.1016/j.quaint.2018.03.014.

\section{References}

Alcaraz, M., Alcolea, J., Balbín, R. de, García Valero, M.A., Yravedra, J., Baena, J., 2013. Los orígenes del Solutrense y la ocupación pleniglaciar del interior de la Península Ibérica. Implicaciones del nivel 3 de Peña Capón (Valle del Sorbe, Guadalajara). Trab. Prehist. 70, 28-53.

Alcaraz, M., Alcolea, J., Kehl, M., Albert, R.M., Baena-Preysler, J., de BalbínBehrmann, R., Cuartero, F., Cuenca-Bescós, G., Jiménez-Barredo, F., LópezSáez, J.A., Piqué, R., Rodríguez-Antón, D., Yravedra, J., Weniger, G.-C., 2017. A context for the last Neandertals of interior Iberia: los Casares cave revisited. PloS one 12 (7), e0180823. https://doi.org/10.1371/journal.pone.0180823.

Álvarez Catalán, V., de los Arcos Fernández, S., Gallego Lletjos, N., Gil Ortiz, C. González García, I., Herráez Igualador, E., Ruiz Zapata, B., Yravedra, J., 2009. Yacimiento Paleolítico del Estanque de Tormentas de Butarque. In: Santonja, M. (Ed.), Actas de las Cuartas Jornadas de Patrimonio Arqueológico en la Comunidad de Madrid. Los primeros pobladores: Arqueología del Pleistoceno, Alcalá de Henares, pp. 333-337.

De los Arcos, S., Gallego, N., Gil Ortiz, C., González García, I., Yravedra, J., 2008. Geoarqueología del yacimiento paleolítico del Estanque de Tormentas de Butarque (Villaverde, Madrid). In: OrJIA (Ed.), Actas de las I Jornadas de Jóvenes en Investigación Aqueológica. Dialogando con la cultura material I, pp. 135-140.

De los Arcos, S., Gallego, N., Gil Ortiz, C., González García, I., Yravedra, J., 2010. El nivel 4 (arcillas) del yacimiento paleolítico del Estanque de Tormentas de Butarque (Villaverde, Madrid). In: Actas de las V jornadas de patrimonio arqueológico en la Comunidad de Madrid. Museo Arqueológico Regional de la Comunidad de Madrid, Alcalá de Henares, Madrid, pp. 287-291.

Baena, J., Baquedano, I. (Eds.), 2010. Las huellas de nuestro pasado. Estudio del Yacimiento del pleistoceno madrileño de Tafesa (Antigua Transfesa), vol. 14, p. 217. Zona Arqueológica.

Barba, R., Domínguez-Rodrigo, M., 2005. The taphonomic relevance of the analysis of bovid long limb bone shaft features and their application to element identification: study of bone thickness and morphology of the medullary cavity. J. Taphon. 3, 17-42.

Behrensmeyer, A.K., 1978. Taphonomic and ecological information from bone weathering. Paleobiology 4, 150-162.

Benito, G., Gutiérrez, F., Pérez-González, A., Machado, M.J., 2000. Geomorphological and sedimentological features in Quaternary fluvial systems affected by solution-induced subsistence (Ebro basin, NE Spain). Geomorphology 33, 206-224.

Benito, G., Pérez-González, A., Gutiérrez, F., Machado, M.J., 1998. River response to 
Quaternary subsidence due to evaporite solution (Gállego River, Ebro Basin, Spain). Geomorphology 22 (3-4), 243-263.

Blain, H.A., Bisbal-Chinesta, J. F., Nartínez-Monzón, A., Panera, J., Rubio-Jara, S. Uribelarrea, D., Yravedra, J., Pérez-González, A., i.p. The middle to late Pleistocene herpetofaunal assemblages from the Jarama and Manzanares valleys (Madrid, central Spain): an ecological synthesis. Quat. Int..

Blain, H.A., Lozano-Fernández, I., Ollé, A., Rodríguez, J., Santonja, M., PérezGonzález, A., 2015. The continental record of marine isotope stage 11 (middle Pleistocene) on the iberian Peninsula characterized by herpetofaunal assemblages. J. Quat. Sci. 30 (7), 667-678.

Blain, H.A., Panera, J., Uribelarrea, D., Rubio-Jara, S., Pérez-González, A., 2012. Characterization of a rapid climate shift at the MIS 8/7 transition in central Spain (Valdocarros II, Autonomous Region of Madrid) by means of the herpetological assemblages. Quat. Sci. Rev. 47, 73-81.

Blain, H.A., Rubio-Jara, S., Panera, J., Uribelarrea, D., Laplana, C., Herráez, E., PérezGonzález, A., 2017a. A new middle Pleistocene (marine oxygen isotope stage 6) cold herpetofaunal assemblage from the central iberian Peninsula (Manzanares Valley, Madrid). Quat. Res. 87 (3), 499-515.

Blain, H.A., Ruiz-Zapata, B., Gil-García, Ma J., Sesé, C., Santonja, M., PérezGonzález, A. 2017b. New palaeoenvironmental and palaeoclimatic reconstructions for the Middle Palaeolithic site of Cuesta de la Bajada (Teruel, eastern Spain) inferred from the amphibian and squamate reptile assemblages. Quat. Sci. Rev. 173, 78-91.

Blumenschine, R.J., 1988. An experimental model of the timing of hominid and carnivore influence on archaeological bone assemblages. J. Archaeol. Sci. 15, 483-502.

Blumenschine, R.J., 1995. Percussion marks, tooth marks, and experimental determinations of the timing of hominid and carnivore access to long bones at FLK Zinjanthropus, Olduvai Gorge, Tanzania. J. Hum. Evol. 29, 21-51.

Brain, C.K., 1969. The contribution of Namib desert Hottentots to understanding of Australopithecus bone accumulations. Sci. Pap. Namib. desert Res. Stn. 32, 1-11.

Brauer, A., Allen, J.R.M., Mingram, J., Dulski, P., Wulf, S., Huntley, B., 2007. Evidence for last interglacial chronology and environmental change from Southern Europe. Proc. Natl. Acad. Sci. U. S. A. 104, 450-455.

Bunn, H.T., 1982. Meat-eating and Human Evolution, Studies on the Diet and Subsistence Patterns of Plio-pleistocene Hominids in East Africa. University of California at Berkeley, p. 384. Ph.D. thesis.

Cacho, C., Martos, J.A., Jordá, F.J., Yravedra, J., Sesé, C., Zapata, L., Avezuela, B., Valdivia, J., Ruiz, M., Marquer, L., Martín, I., Tejero, J.M., 2012. Human landscapes of the Late Glacial Period in the interior of the Iberian Peninsula: La Peña de Estebanvela (Segovia, Spain). Quat. Int. 272-273, 42-54.

Cacho, C., Martos, J.A., Yravedra, J., Ortega, P., Martín-Lerma, I., Avezuela, B., Zapata, L., Ruiz, M., Valdivia, J., 2016. On the use of space at La Peña de Estebanvela (Ayllón, Segovia, Spain): an approach to economic and social behaviour in the Upper Magdalenian. Quat. Int. 412 (Parta A), 44-53.

Cohen, K.M., MacDonald, K., Joordens, J.C.A., Roebroeks, W., Gibbard, P.L., 2012. The earliest occupation of north-west Europe: a coastal perspective. Quat. Int. 271, 70-83.

Corchón, M.S. (Ed.), 1997. La cueva de la Griega de Pedraza. Arqueología en Castilla y León. Memorias 3. Zamora.

Daujeard, C., Fernandes, P., Guadelli, J.L., Monchel, H.M., Santagata, C., Raynal, J.P., 2012. Neanderthal subsistence strategies in southeastern France between the plains of the rhone valley and the mid-mountains of the massif central (MIS 7 to MIS 3). Quat. Int. 252, 32-47.

D'Errico, F. Sánchez Goñi, M.F., 2003. Neanderthal extinction and the millennial scale climatic variability of OIS 3. Quat. Sci. Rev. 22, 769-788.

Domínguez-Alonso, R.M., De los Arcos-Fernández, S., Ruiz-Zapata, B., Gil, J., 2009, Nuevos datos sobre la Terraza Compleja de Butarque en Villaverde Bajo. In: IV Jornadas sobre Patrimonio Arqueológico de la Comunidad de Madrid. Alcalá de Henares, Madrid, pp. 339-343.

Domínguez-Rodrigo, M., 1997. Meat eating by early hominids at FLK Zinj 22 Site, Olduvay Gorge Tanzania, an experimental a roach using cut-mark data. J. Hum. Evol. 33, 669-690.

Domínguez-Rodrigo, M., de Juana, S., Galán, A.B., Rodríguez, M., 2009. A new protocol to differentiate trampling marks from butchery cut marks. J. Archaeol. Sci. 36, 2643-2654.

Egeland, C., Nielsen, T.K., Byo, M., Kjaergaard, C.K., Larsen, N., Riede, F., 2014. The taphonomy of fallow deer (Dama dama) skeletons from Denmark and its bearing on the pre-Weichselian occupation of northern Europe by humans. Archaeol. Anthropol. Sci. 6, 31-61.

Goy, J.L., Pérez-González, A., Zazo, C., 1989. Cartografía y Memoria del Cuaternario y Geomorfología, Hoja de Madrid (559). Mapa Geológico de España. Escala 1: 50.000, 2a Serie (MAGNA). IGME. Servicio de Publicaciones del Ministerio de Industria, Madrid.

Hérisson, D., Brenet, M., Cliquet, D., Moncel, M.H., Richter, J., Scott, B., Baelen, A.V., Modica, K., Loecker, D., Ashton, N., Bourguignon, L., Delagnes, A., Faivre, J.P. Folgado, M., Locht, J.L., Pope, M., Raynal, J.P., Roebroeks, W., Santagata, C., Turq, A., Van Peer, P., 2016. The emergence of the middle Paleolithic in northwesterb Europe and its southern fringes. Quat. Int. 411 (Part A), 233-283.

Hublin, J.J., Roebroeks, W., 2009. Ebb and flow or regional extinctions? On the character of Neandertal occupation of northern environments. Comptes Rendus Palevol 8, 503-509.

Jochim, M.A., 1987. Late Pleistocene refugia in Europe. In: Soffer, O. (Ed.), The Pleistocene Old World: Regional Perspectives. Interdisciplinary contributions to Archaeology, Plenum Press, New York, pp. 317-332.
Laplana, C., Herráez, E., Yravedra, J., Bárez, S., Uribelarrea, D., Rubio-Jara, S., Panera, J., Pérez-González, A., 2015. Biocronología de la Terraza Compleja de Butarque en el río Manzanares en el Estanque de Tormentas al sur de Madrid. Estudios Geológicos 71(1), e028. https://doi.org/10.3989/egeol.41808.338.

López-Recio, M., 2017. Contextualización geoarqueológia y cronocultural de yacimientos del Pleistoceno medio y superior de Madrid. PhD. UAM, Madrid.

Moreno, D., Duval, M., Rubio-Jara, S., Panera, J., Bahain, J.J., Shao, Q., Pérez-González, A., Falguères, C., i.p., ESR dating of several Middle to Late Pleistocene archaeopaleontological sites from the Manzanares and Jarama river valleys (Madrid basin, Spain). Quat. Int.. https://doi.org/10.1016/j.quaint.2017.09.003.

Panera, J., 2009. La ocupación del medio fluvial en el Paleolítico antiguo. Caracterización geoarqueológica de depósitos pleistocenos del valle del río Jarama (Madrid) y estudio tecnoeconómico de la industria lítica. Tesis Doctoral. Departamento de Prehistoria y Arqueología. Facultad de Geografía e Historia. Universidad Nacional de Educación a Distancia, Inédita, 705 pp.

Panera, J., Rubio-Jara, S. (Eds.), 2002. Bifaces y elefantes. La investigación del Paleolítico Inferior en Madrid. Zona Arqueológica, vol. 1. Museo Arqueológico Regional de la Comunidad de Madrid, Madrid, pp. 215-241.

Panera, J., Rubio-Jara, S., Yravedra, J., Blain, H.A., Sesé, C., Pérez-González, A., 2014. Manzanares Valley (Madrid, Spain): a good country for proboscideans and Neanderthals. Quat. Int. 326-327, 329-343.

Panera, J., Torres, T., Pérez-González, A., Ortiz, J.E., Rubio-Jara, S., Uribelarrea, D. 2011. Geocronología de la Terraza Compleja de Arganda en el valle del río Jarama (Madrid, España). Estud. Geol. 67 (2), 495-504.

Pérez-González, A., 1971. Estudio de los procesos de hundimiento en el valle del río Jarama y sus terrazas (nota preliminar). Estud. Geol. XXVII (4), 317-324.

Pérez-González, A., 1994. Depresión del Tajo. In: Elorza Gutiérrez, M. (Ed.), Geomorfología de España, Rueda, pp. 389-436.

Pérez-González, A., Rubio-Jara, S., Panera, J., Uribelarrea, D., 2008. Geocronología de la sucesión arqueoestratigráfica de Los Estragales en la Terraza Compleja de Butarque (Valle del río Manzanares, Madrid). Geogaceta 45, 39-42.

Roebroeks, W., Conard, N.J., van Kolfschoten, T., 1992. Dense forests, cold steppes, and the Palaeolithic settlement of northern Europe. Curr. Anthropol. 33 (5) $551-586$.

Roebroeks, W., Villa, P., 2011. On the earliest evidence for habitual use of fire in Europe. Proc. Natl. Acad. Sci. 108, 5209-5214.

Rubio-Jara, S., 2011. El paleolítico en el valle del río Manzanares (Madrid). Caracterización geoarqueológica de depósitos pleistocenos y estudio tecnoeconómico de la industria lítica (Tesis Doctoral inédita). Universidad Nacional de Educación a Distancia.

Rubio-Jara, S., Panera, J., Rodríguez de Tembleque, J., Santonja, M., PérezGonzález, A., 2016. Large flake Acheulean in the middle Tagus basin (Spain): middle stretch of the river Tagus valley and lower stretches of the rivers Jarama and Manzanares valleys. Quat. Int. 411, 349-366.

Rus, I., Vega, G., 1984. El yacimiento de Arriaga II: problemas de una definición actual de los suelos de ocupación. In: Primeras Jornadas de Metodología e investigación Prehistórica (Soria, 1981). Ministerio de Cultura, pp. 387-404.

Santonja, M., López Martínez, N., Pérez-González, A., 1980. Ocupaciones achelenses en el valle del Jarama. Arqueología y Paleontología, I. Diputación Provincial de Madrid).

Santonja, M., Pérez-González, A. (Eds.), 2005. Los yacimientos paleolíticos de Ambrona y Torralba (Soria), p. 444. Un siglo de investigaciones Arqueológicas. Zona Arqueológica 5.

Santonja, M., Pérez-González, A., Domínguez-Rodrigo, M., Panera, J., Rubio-Jara, S. Sesé, C., Soto, E., Arnold, 1. J., Duval, M., Demuro, M., Ortíz, J.E., Torres, T. Mercier, N., Barba, R., Yravedra, J., 2014a. The Middle Paleolithic site of Cuesta de la Bajada (Teruel, Spain): a perspective on the Acheulean and Middle Paleolithic technocomplexes in Europe. J. Archaeol. Sci. 49, 556-571.

Santonja, M., Pérez-González, A., Panera, J., Rubio-Jara, S., Méndez-Quintas, E., 2016. The coexistence of acheulean and ancient middle palaeolithic technocomplexes in the middle Pleistocene of the iberian Peninsula. Quat. Int. 411, 367-377.

Santonja, M., Pérez-González, A., Panera, J., Rubio-Jara, S., Sesé, C., Soto, E., SánchezRomero, L., 2014b. Ambrona and Torralba archaeological and paleontological sites, Soria. In: Sala Ramos, R. (Ed.), Pleistocene and Holocene Hunter-gatherers in Iberia and the Gibraltar Strait: the Current Archaeological Record. Universidad de Burgos and Fundación Atapuerca, pp. 561-567.

Santonja, M., Villa, P., 1990. The lower paleolithic of Spain and Portugal. J. World Prehistory 4 (1), 45-94.

Silva, P.G., López-Recio, M., Tapias, F., Roquero, E., Morín, J., Rus, I., CarrascoGarcía, P., Giner-Robles, J.L., Rodríguez-Pascua, M.A., Pérez-López, R., 2013. Stratigraphy of the Arriaga Palaeolithic sites. Implications for the geomorphological evolution recorded by thickened fluvial sequences within the Manzanares River valley (Madrid Neogene Basin, Central Spain). Geomorphology 196, 138-161.

Stewart, J.R., Stringer, C.B., 2012. Change human evolution out of africa: the role of refuge and climate. Science 335, 1317-1321. https://doi.org/10.1126 science.1215627.

Straus, L.G., 1991. Human geography of the late upper paleolithic in western Europe present state of the question. J. Anthropol. Res. 46 (2), 259-278.

Thompson, C.E., Ball, S., Thompson, T.J.U., Gowland, R., 2011. The abrasion of modern and archaeological bones by mobile sediments: the importance of transport modes. J. Archaeol. Sci. 38, 784-793.

Vaquero, M., 2006. El tránsito Paleolítico Medio/Superior en la Península Ibérica y la Frontera del Ebro. Coment. a Zilhão. Pyrenae 37, 107-129.

Villa, P., Mahieu, E., 1991. Breakage patterns of human long bones. J. Hum. Evol. 21 
$27-48$.

Voorhies, M., 1969. Taphonomy and Population Dynamics of an Early Pliocene Vertebrate Fauna, Knox Country, Nebraska. Special paper 1. Univ. of Wyoming Press Department of Geology and Geophysics, p. 69.

Yravedra, J., 2010. Estudio tafonómico y zooarqueológico de los macromamíferos del yacimiento arqueológico de TAFESA (Madrid). In: Baena, J., Baquedano, I. (Eds.), Las huellas de nuestro pasado. Estudio del yacimiento del Pleistoceno Madrileño de Tafesa (Antigua Transfesa), Museo Arqueológico Regional de la Comunidad de Madrid. Zona Arqueológica, vol. 14, pp. 155-176.

Yravedra, J., Domínguez-Rodrigo, M., 2009. The shaft-based methodological approach to the quantification of long limb bones and its relevance to understanding hominin subsistence in the Pleistocene: application to four Paleolithic sites. J. Quat. Sci. 24, 85-96.

Yravedra, J., Domínguez-Rodrigo, M., Santonja, M., Pérez-González, A., Panera, J., Rubio-Jara, S., Baquedano, E., 2010. Cut marks on the middle Pleistocene elephant carcass of Áridos 2 (Madrid, Spain). J. Archaeol. Sci. 37, 2469-2476.

Yravedra, J., Julien, M.A., Alcaraz, V., Alcolea González, J., de Balbín-Behrmann, R., Lécouver, C., Marcel, C.H., Burke, A., 2016. Not so deserted...paleoecology and human subsistence in Central Iberia (Guadalajara, Spain) around the Last Glacial Maximum. Quat. Sci. Rev. 140, 21-38. 